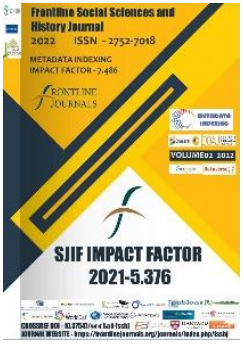

Journal Website: https://frontlinejournal s.org/journals/index.ph $\mathrm{p} /$ fsshj

Copyright: Original content from this work may be used under the terms of the creative commons attributes 4.0 licence.
Research Article

\section{THE ROLE OF INTERACTIVE METHODS IN TEACHING THE CREATIVITY OF MUHAMMAD YUSUF}

Submission Date: January 11, 2022, Accepted Date: January 20, 2022,

Published Date: January 31, 2022

Crossref doi: https://doi.org/10.37547/social-fsshj-02-01-11

Nigora Sulaymonovna Saydakhmedova

Independent Researcher of Namangan State University, Uzbekistan

\title{
Abstract
}

This article explores interesting methods and games used to teach Muhammad Yusuf's works, highlighting the effectiveness of innovative teaching that helps the teacher engage the student in the learning process.

\section{KEYWORDS}

Cluster, debate, crossword, glabingo, bahri byte, research, presentation.

\section{INTRODUCTION}

The future of every nation is determined by the quality of education provided to the younger generation. The main factor in the organization of education is considered a good lesson. The good lesson aims to integrate students's active participation. The role of the teacher should be a 
(ISSN - 2752-7018)

VOLUME 02 ISSUE 01 Pages: 86-93

SJIF IMPACT FACTOR (2021: 5. 376)

OCLC - 1276789625 METADATA IF - 7.569

facilitator while students are active participants during the lesson. Achieving educational effectiveness in accordance with the criteria set out in the Law "On Education" is one of the important tasks facing every educator [1].

In order to organize lessons in an non-traditional way, it is necessary to integrate new methods in every lesson. Where there is no activity, there is no decision-making and development of the individual. In order to engage a student in a lesson, the teacher must be able to explain the learning material in an interesting way, related to real life, demonstrate its practical significance, use advanced, interactive methods, test cognitive skills through tests, ratings, create a positive climate, and demonstrate results. The basis of knowledge is practice. Knowledge that is not applied in practice is like a fruitless tree. So unless there is a connection between theory and practice, there can be no question of knowledge. Students should be able to see for themselves how to apply the knowledge gained in school in life and in practice.

In this case, the teacher must be able to use innovative methods and implement them. The book written by Professor S. Matchon entitled "Do you know how to read a book?" which provides information on developing culture of reading. The author highlights that the reader will receive knowledge of life and its laws from textbooks, feel the power of the mind and record in their memory. However, these knowledge and assumptions do not affect the feelings in the slightest. While reading a book, you will have an active attitude. Your heart will be filled with endless joy - you will be inspired, you will be angry, you will suffer. Because the heart is created because of pain, and pain does not leave the interlocutor indifferent". In order to solve the problems facing the education system in the current innovative processes, it is necessary to educate autonomous students who are able to assimilate new information and evaluate the acquired knowledge by themselves. Therefore, the role and importance of modern teaching methods - interactive methods, innovative technologies in the educational process of institutions is incomparable. There are many ways to teach literature today. These methods can be used according to the age, psychological characteristics, level of knowledge of students. In terms of teaching Muhammad Yusuf's poems to students at school, we have identified new methodological methods in the articles written by Abdurahmanova (National Anthem in the works 
(ISSN - 2752-7018)

VOLUME 02 ISSUE 01 Pages: 86-93

SJIF IMPACT FACTOR (2021: 5 • 376)

OCLC - 1276789625 METADATA IF -7.569

of Muhammad Yusuf), G. Mamajanova (Our Muhammad Yusuf), L. Rustamova (Life shining like lightning), Zulaykho Zaynitdinova (Teaching the works of Muhammad Yusuf on the basis of research) [2] and L. Akramova (The experiences of studying the works of Muhammad Yusuf in 8th grade) [3]. We highly recommend the following methods in teaching the poet's work.

\section{Lead-in}

The "Good wishes" method. Students are assigned to wish each other well. A wish told only once should not be repeated. For example, "May you always have good luck", "May your grades be only" five "," May you become a good child as your parents will"," May you be a member of the Supreme Council in the future "," I want you to become a President "," May all your dreams come true ", "Let you become a Professor", "I want you to become a winner of the Nobel Award", "Let you become a master of your future profession", "May Allah reward you to become a poet of Uzbekistan", " May Allah reward you to be a Hero of Uzbekistan" etc. At the end of the activity, the student who wished a lot is encouraged as the winner.

How would you describe Muhammad Yusuf?
In the "cluster" method, groups write answers, and the group responses are encouraged through pictures describing our national skullcaps. Behind the pictures are examples of the poet's poems. The lesson is conducted in a competitive manner.

\section{Develop the previous lesson topic:}

Based on the additional information provided by the teacher in the previous lesson and the information in the textbook, the topic "Find more!" method. The works of Muhammad Yusuf are presented on a slide, mixed with the works of Tora Sulayman, and students write in a notebook only the poem collections of Muhammad Yusuf. The correct answer is given on the next slide. Students can cross-check each other's answers. The winning team will be identified and encouraged.

On the basis of the "debate" method, Muhammad Yusuf's poems about the homeland are analyzed in a group discussion.

\section{Questions:}

1. What spirit reigned in the poet when he entered the field of literature? Can you prove 
(ISSN - 2752-7018)

VOLUME 02 ISSUE 01 Pages: 86-93

SJIF IMPACT FACTOR (2021: 5 • 376)

OCLC - 1276789625 METADATA IF -7.569

Publisher: Frontline Journals

your answer with a couple of literary examples?

2. Reflect on the work of Muhammad Yusuf during the years of independence. Do you know any songs based on his poems? Which group can sing that song?

3. Which great figures are mentioned in the poem "Vatanim" (My Homeland) ? By what qualities and analogies are they glorified?

4. Why is this poem "Vatanim" (My Homeland) so popular?

5. Explain the content of the poem "Mehr qolur" (Mercy will remain) and the following bytes in the poem "O'tar qancha yillar to'zoni, Yulduzlar -ko'z yoshi samoni" (How many years will pass, the stars - the straw of tears)

6. When does love make the world narrow? To whom does the world seem narrow?

7. Why does he say "O'tmishingni o'ylab og'riydi jonim" (my soul hurts thinking about your past) in the poem "Yurtim, adolat bo'lmas armonlaring bor" ? Can anyone explain these statements of the poet?

8. Do you know about "yulduzni yig'lagan dostonlari" (the country's star-crying epics"? Is it only about the examples of Uzbek folklore, or is there other content?
9. To whom does the poet refer when he says "Qurboning bo'layin, ey onajonim" (May I be a victim, my dear mother"? Think about what additional meanings this appeal added to the meaning in the poem.

In what ways is Muhammad Yusuf's poetry very close to the hearts of the people? Can you justify it with examples?

We test knowledge. Crosswords are distributed to each group of students based on Muhammad Yusuf's life and work. The student from each group goes to the blackborad and solves the crossword puzzles turn by turn.

\section{"I test my knowledge" method}

\section{Crossword questions for group \# 1 :}

1. The region where Muhammad Yusuf was born.

2. One of the main themes of the poet's poetry.

3. Singer who sang the poems of the poet Usmanova.

4. His wife is a poetess ......... as-salam.

5. The creature that the poet saw "eyes full of tears."

6. Name of Muhammad Yusuf's daughter.

7. The famous poem sung by the singer Ohun Madaliev. 


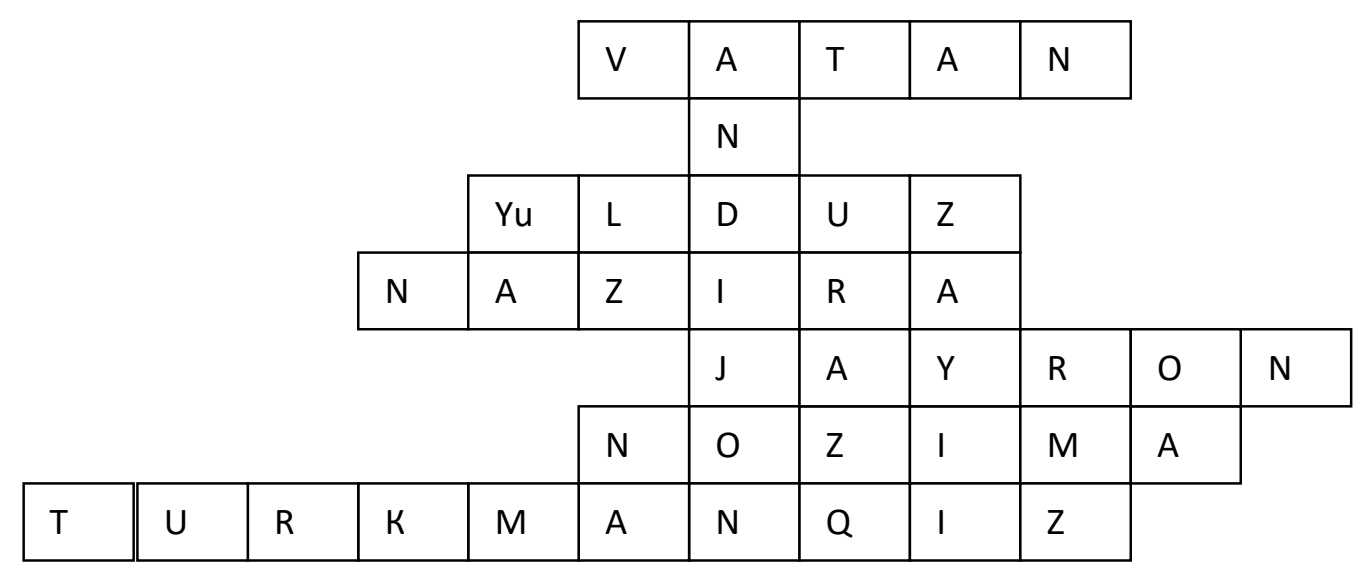

\section{Crossword questions for group \#2}

1. The district where the poet was born.

2. In the poet's description, a feeling that lasts forever even at the end of time.
3. The Epic of Muhammad Yusuf.

4. One of the main themes of the poet's poetry.

5. The name of the poet's collection of poems.

6. The poet's daughter.

7. The name of the poet's mother.

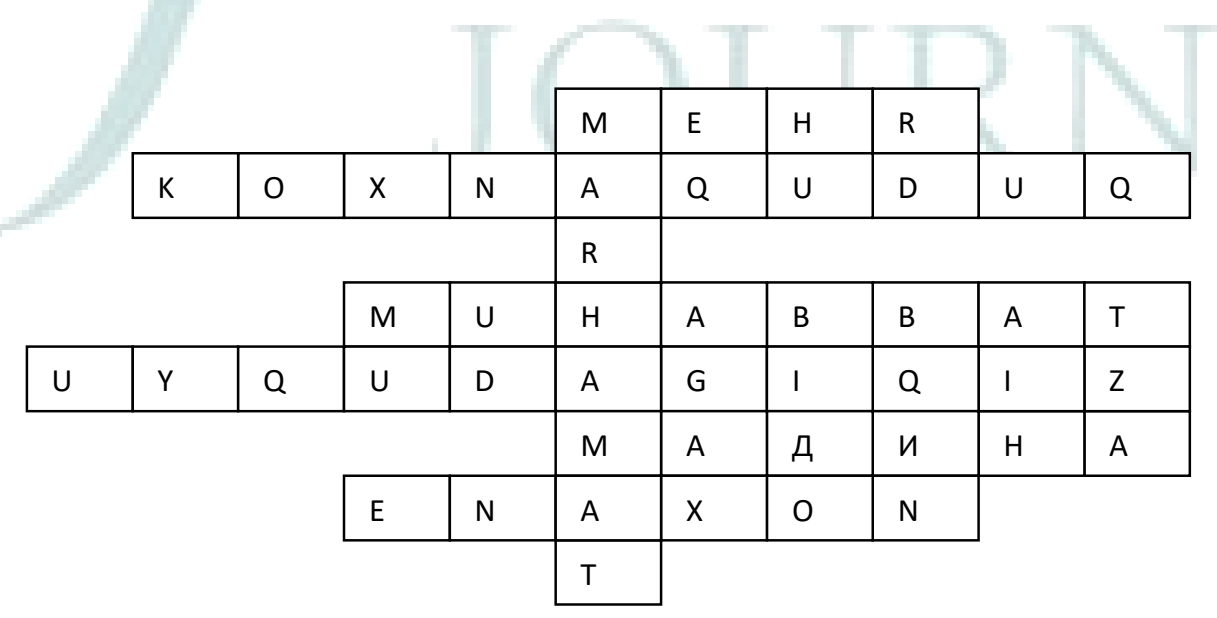

Crossword questions for group \# 3 :

1. The village where the poet was born.
2. A poem written by the poet in honor of Mirzo Ulugbek. 
(ISSN - 2752-7018)

VOLUME 02 ISSUE 01 Pages: 86-93

SJIF IMPACT FACTOR (2021: 5 • 376)

OCLC - 1276789625 METADATA IF - 7.569

\section{Crossref do \\ Publisher: Frontline Journals}

3. One of the main themes of the poet's poetry.

4. The poem who sung by a singer Muhriddin Holikov

5. One of the epics he created.
6. A song sung by the poet by a singer Sevara Nazarkhan.

7. A poem written by the poet dedicated to the memory of Shavkat Rahmon

\begin{tabular}{l}
$\qquad$\begin{tabular}{|l|l|l|l|l|l|l|l|l|l|l|}
\hline S & A & M & A & R & Q & A & N & D \\
\hline X & O & L & I & Q & O & V & \multicolumn{1}{l|l}{} \\
\hline & Q & O & R & A & Q & U & Yo & Sh & Sh \\
\hline
\end{tabular} \\
\hline
\end{tabular}

Main activity: "Find it"

Students show their talents in a way called 'Find it'. They have to say which singer sang the poem. Encouragement pictures will be added to the Spirituality Tree:

The lesson will continue on the basis of the Glabingo method. The teacher plays the rubab. The tune is called "Go'zal tong" (Beautiful Morning). The group who knows the name of the tune says "Glabingo". Students say the meaning of the word rubab, the name of the melody, and what the 4th type of treatment in medicine is called. It is known that in the East, musical instruments were named after their effects on the human body and psyche. Rubab is derived from the words "Rukh" (spirit) and "Bob" (body) and affects the human spirit with its softness and lightness. At the end of the task, one of the members of the group sings or dances based on the poems of Muhammad Yusuf.

The research-presentation method. Details of interesting events related to the life and work of the poet will be presented on the stage. The 
(ISSN - 2752-7018)

VOLUME 02 ISSUE 01 Pages: 86-93

SJIF IMPACT FACTOR (2021: 5. 376)

OCLC - 1276789625 METADATA IF - 7.569

groups perform homework based on the performances of "Zogora Kulcha" (bread prepared by corn wheat) and "Ona men keldim, degin" (Mom, say I've come).

In the next task, students present their drawings based on the poet's life and work. The participants of the group will demonstrate the skirts, shirts and various handicrafts sewn on labor education. They comment on their knowledge of the science of drawing, that is, they talk about the edges and decorations of the skullcap. Poems of the poet "Turkmen girl", "Mother" are sung by students. The performance of melodies and songs will be evaluated by a music teacher, handicrafts by a labor science teacher, and the decoration of a skullcap and shirt will be evaluated by a drawing teacher.

\section{Follow-up:}

Bahri byte. Groups compete on the poet's poems. The teacher sings a poem by the poet's wife, Nazira as Salom, entitled "Sizdan o'zga" (Besides You). In the "Memory from You" method, students present their drawings based on the poet himself or his poems. For example, the poet's poems such as "Binafsha" (Purple), "Do'ppi kiymay qo'ydi odamlar" (People not wearing skullcap),
Lolaqizg'aldoq (Tulip), “Jayron" (Deer). The participants of the group will demonstrate the skirts, shirts and various handicrafts sewn on labor education. They comment on their knowledge of the science of drawing, they talk about the edges and decorations of the skullcap. Poems of the poet "Turkmen girl", "Mother" are sung by students. The performance of melodies and songs will be evaluated by a music teacher, handicrafts by a labor science teacher, and the decoration of a dope and shirt will be evaluated by a drawing teacher.

TV guest method. Gulchehra Yusupova, the poet's sister, his nieces and nephews, poet's wife Nazira as Salom will be invited to the open TV lesson. (This meetings can also be arranged through the zoom program). They share their memories of the poet. The scores of the groups will be announced. The teacher concludes the lesson with the following poem by the poet:

O'tar qancha yillar tuzoni,

Yulduzlar ko'z yoshi samoni,

O'tar inson yaxshi-yomoni.

Mehr qolur, ish qolur. 
(ISSN - 2752-7018)

VOLUME 02 ISSUE 01 Pages: 86-93

SJIF IMPACT FACTOR (2021: 5 • 376)

OCLC - 1276789625 METADATA IF - 7.569

(Meaning: Regardless, how many years pass, stars stay tearing in the sky, good and bad people live and die, but Mercy remains, love remains.
3. Akramova L. (2009) The experiences of studying the works of 8th grade Muhammad Yusuf, Journal of Language and Literature Education, 2009, No. (5)9.

\section{Conclusion}

As the conclusion, we can mention that students will integrate and develop skills when teaching using innovative methods in the classroom. Almost all students are involved in the lesson process and their interest in the lesson increases. The lesson is the main criterion for determining the scientific and scientific-pedagogical skills of the teacher. This shows the essence of comparing an hour-long lesson to a major work of art. Interactive methods serve as a unique resource in reorienting literature lessons in general secondary education to a new level, both in terms of form and content and provides opportunities for students to learn crafts in their future independent learning.

\section{ReFERENCES}

1. The Law of the Republic of Uzbekistan, O'RQ637 No. 23.09.2020. www.lex.uz

2. A collection of scientific and methodological articles on modern Uzbek poetry and modern teaching methods. Namangan : 2014. pp.18 $24-42$. 